\title{
Dietary Supplementation with Enterococcus faecium R1 Attenuates Intestinal and Liver Injury in Piglets Challenged by Lipopolysaccharide
}

\author{
Yanyan Zhang ${ }^{\dagger}$, Tao $\mathrm{Wu}^{\dagger}{ }^{\dagger}$, Zhenqiang Chen ${ }^{\dagger}$, Yuxuan Meng, Zhekun Zhu, Qian Wang, Junjie Tian, Dan Yi, \\ Lei Wang, Di Zhao and Yongqing Hou *
}

check for updates

Citation: Zhang, Y.; Wu, T.; Chen, Z.; Meng, Y.; Zhu, Z.; Wang, Q.; Tian, J.; Yi, D.; Wang, L.; Zhao, D.; et al. Dietary Supplementation with Enterococcus faecium R1 Attenuates Intestinal and Liver Injury in Piglets Challenged by Lipopolysaccharide. Animals 2021, 11, 1424. https:// doi.org/10.3390/ani11051424

Academic Editor: José

Francisco Pérez

Received: 24 March 2021

Accepted: 14 May 2021

Published: 16 May 2021

Publisher's Note: MDPI stays neutra with regard to jurisdictional claims in published maps and institutional affiliations.

Copyright: (c) 2021 by the authors. Licensee MDPI, Basel, Switzerland. This article is an open access article distributed under the terms and conditions of the Creative Commons Attribution (CC BY) license (https:/ / creativecommons.org/licenses/by/ $4.0 /)$.
Hubei Key Laboratory of Animal Nutrition and Feed Science, Wuhan Polytechnic University, Wuhan 430023, China; zhangyanyana305@163.com (Y.Z.); wutao@whpu.edu.cn (T.W.); chen07928263206@163.com (Z.C.); m13871101699@163.com (Y.M.); zhuzhekun1207@163.com (Z.Z.); w1353807950@163.com (Q.W.); tianjunjie9523@163.com (J.T.); yidan810204@whpu.edu.cn (D.Y.); wanglei_wh@aliyun.com (L.W.); zhaodi@whpu.edu.cn (D.Z.)

* Correspondence: houyq@aliyun.com

+ These authors contributed equally to this work and should be considered co-first authors.

Simple Summary: The biological characteristics of E. faecium R1 and the effect of dietary supplementation with E. faecium R1 on the growth performance of weaned piglets were studied. The results showed that E. faecium R1 had the characteristics of effective bacteriostatic activity, acid resistance, bile salt resistance, and high-temperature resistance. Dietary supplementation with E. faecium R1 $\left(6.5 \times 10^{6} \mathrm{CFU} / \mathrm{g}\right)$ improved intestinal function of weaning piglets by decreasing diarrhea incidence. Further research found that dietary supplementation with E. faecium R1 (6.5 × 106 CFU/g) attenuated intestinal and liver injury in piglets challenged by lipopolysaccharide.

Abstract: In this study, a strain of E. faecium R1 with effective bacteriostatic activity, acid resistance, bile salt resistance, high-temperature resistance was screened. To study the effect of E. faecium R1 on lipopolysaccharide (LPS)-induced intestinal and liver injury in piglets, twenty-four weaned female piglets were randomly assigned into one of three groups (8 piglets per group). Piglets in the control group and LPS group were fed a basal diet, piglets in the E. faecium group were fed the basal diet supplemented with E. faecium R1 $\left(6.5 \times 10^{6} \mathrm{CFU} / \mathrm{g}\right)$. On day 21 of the trial, piglets in the LPS group and E. faecium group were intraperitoneally administered LPS $(100 \mu \mathrm{g} / \mathrm{kg})$, piglets in the control group were administered the same volume of saline. Subsequently, blood samples were collected at $3 \mathrm{~h}$, and intestinal, liver, and pancreas samples were collected at $6 \mathrm{~h}$. Results showed that $E$. faecium R1 supplementation significantly decreased the diarrhea rate and feed to gain ratio, and dramatically reduced LPS-induced intestinal and liver injury in piglets. Compared with the LPS group, E. faecium R1 supplementation significantly increased the content of glucagon in plasma and IL-1 $\beta$ in the liver, and the mRNA levels of villin in jejunum and ileum and $B c l-x L$ and $p B D-L$ in the ileum, and significantly decreased the contents of prostaglandin 2 and malondialdehyde in the liver and the activities of myeloperoxidase and aspartate aminotransferase in plasma in piglets. Moreover, E. faecium R1 improved the pancreatic antioxidant capacity in piglets, which was indicated by a significant increase in catalase activity and a decrease in total nitric oxide synthase activity. In summary, dietary supplementation with E. faecium R1 alleviates intestinal and liver injury in LPS-challenged piglets.

Keywords: weaned piglet; growth performance; E. faecium R1; lipopolysaccharide; intestine; liver

\section{Introduction}

Weaning and the weaning diet seriously threaten the intestinal health of piglets. Diarrhea caused by weaning and the weaning diet is a very common disease, which 
eventually develops into growth retardation and seriously restricts the development of the pig industry [1-3]. Therefore, the feeding of weaned piglets directly affects the growth of pigs during the fattening period $[4,5]$. Although feed antibiotics can effectively alleviate diarrhea and reduce the incidence of disease in piglets, many countries have banned the use of in-feed antibiotics because of their potential harm to animal production $[6,7]$. Therefore, healthy and safe antibiotic substitutes will be very important for the healthy growth of animals. Many studies have shown that probiotics can prevent diarrhea in piglets, enhance immune function and improve the growth performance of piglets [8-12]. Probiotic preparation is a kind of micro-ecological preparation made from living microorganisms, which have been widely used in animal farming in recent years and to improve the growth performances of animals [9].

Enterococcus faecium (E. faecium) is a gram-positive coccus and belongs to the Enterococcus genus. In addition, E. faecium is a kind of facultative anaerobic lactobacillus that can colonize the digestive tract of humans and animals [10]. Some studies have reported that Enterococcus can promote the growth of animals by forming dominant microorganisms in the gastrointestinal tract [11-14]. Therefore, E. faecium may be used as a potential antibiotic substitute in animal production to improve the safety of livestock and poultry products.

Although probiotics are safe and effective antibiotic substitute, not all probiotics can be used as feed additives due to the complex physiological environment of the gastrointestinal tract. Because most microorganisms that enter the stomach cannot survive in the acidic gastric environment [15]. Even if a few microorganisms survive in the stomach, they have to resist a strong destructive effect of bile salts in the small intestine on the cell membrane [16-18]. Besides, high temperature during feed pelleting can kill most probiotics $[19,20]$. In short, stomach acid, bile salts, and high temperature seriously affect the application value of probiotics in feed. Therefore, to produce safe and efficient probiotic preparations, the screened probiotic strains can not only promote animal growth but also have stable biological characteristics.

In this study, a strain of E. faecium R1 with stable biological characteristics was screened from multiple probiotic strains. We hypothesized that dietary supplementation with $E$. faecium R1 may improve the growth performance of weaned piglets and alleviate tissue damage in piglets challenged by LPS. The purpose of this research was to test this hypothesis and to elucidate the underlying molecular mechanisms.

\section{Materials and Methods}

\subsection{Strains and Growth Condition}

Ten strains of probiotic were isolated from intestinal contents in pigs fed commercial compound feeds according to the general method described previously [21,22], which were grown at $37^{\circ} \mathrm{C}$ in MRS medium. Escherichia coli K88 (E. coli K88) was gifted by the key laboratory of agricultural microbiology, Huazhong Agricultural University, which was cultured in LB medium.

\subsection{Biological Characteristics of Isolated Probiotics}

To determine the bacteriostasis of isolated probiotic strains against pathogenic E. coli $\mathrm{K} 88$, the bacteriostasis circle diameters were determined by the oxford cup method [23] with minor modifications. First of all, the pathogenic E. coli K88 was cultured for 12-24 h and diluted 20 times. Secondly, $100 \mu \mathrm{L}$ of E. coli K88 diluent was evenly plated on the sterile agar plate. Finally, the oxford cup was placed vertically on the surface of the culture medium and gently press to make it contact with the culture medium without any gaps. Subsequently, the probiotic strains $\left(100 \mu \mathrm{L} / \mathrm{cup}, 1.0 \times 10^{7} \mathrm{CFU} / \mathrm{mL}\right)$ were added to the oxford cup and cultivated at $37^{\circ} \mathrm{C}$ for $1-18 \mathrm{~h}$. The bacteriostasis circle diameters were measured by using vernier calipers.

To determine the tolerance of isolated probiotic strains to high temperature, these probiotic strains cultured to logarithmic phase were transferred to sterile phosphate-buffered saline (PBS) (1:100). Before incubation in a water bath, the number of initial probiotic strains 
in PBS was counted by plate counting method, respectively. After being incubated in PBS respectively in a water bath at $60^{\circ} \mathrm{C}, 75^{\circ} \mathrm{C}$, or $90^{\circ} \mathrm{C}$ for $10 \mathrm{~min}$, the number of probiotic strains was counted by plate counting method. Finally, survival rates were calculated separately. Survival rate $(\%)=$ the number of probiotic strain after culture for $10 \mathrm{~min}$ at $60^{\circ} \mathrm{C}, 75^{\circ} \mathrm{C}$, or $90^{\circ} \mathrm{C} /$ the amount of initial probiotic strain $\times 100$.

To determine the tolerance of isolated probiotic strains to acid, these probiotic strains cultured to logarithmic phase were transferred to PBS (1:100) with different $\mathrm{pH}$ values (1.5, $2.5,3.5)$, respectively. After incubation at $37^{\circ} \mathrm{C}$ for $3 \mathrm{~h}$, the number of the probiotic strains in PBS with different $\mathrm{pH}$ was separately counted by plate counting method. Finally, survival rates were calculated separately. Survival rate $(\%)=$ the number of probiotic strains after culture for $3 \mathrm{~h}$ at different $\mathrm{pH}$ values $(1.5,2.5,3.5) /$ the amount of initial probiotic strain $\times 100$.

To determine the tolerance of isolated probiotic strains to bile salt, these probiotic strains cultured to logarithmic phase were transferred to PBS (1:100) with different concentrations of bile salts $(0.1 \%, 0.3 \%$, and $0.5 \%)$, respectively. After incubation at $37^{\circ} \mathrm{C}$ for $3 \mathrm{~h}$, the number of the probiotic strains in PBS with different concentrations of bile salts was separately counted by the plate counting method. Finally, survival rates were calculated separately. Survival rate $(\%)=$ the number of probiotic strain after culture for $3 \mathrm{~h}$ at different concentrations of bile salts $(0.1 \%, 0.3 \%$, and $0.5 \%) /$ the amount of initial probiotic strain $\times 100$.

\subsection{Animals and Experimental Design}

The study was conducted after approval by the Institutional Animal Care and Use Committee at Wuhan Polytechnic University (No. WPU202011002).

To study the effect of E. faecium R1 on the growth performance of weaned piglets, twenty-four 3-week-old healthy crossbred female piglets (Duroc $\times$ Landrace $\times$ Yorkshire) were weaned and purchased from a commercial pig farm. The feeding and management of animals were performed as previously described [24] with some modifications. After a 4-day adaptation period, piglets ( 25 days of age, average body weight of $6.50 \pm 0.43 \mathrm{~kg}$ ) were randomly assigned into one of three groups (8 piglets per group). Group 1 , which was fed the basal diet, served as a control group. Group 2, which was fed the basal diet with subsequent lipopolysaccharide (LPS) challenge on day 21, served as the LPS group. Group 3, which was fed the basal diet supplemented with E. faecium R1 $\left(6.5 \times 10^{6} \mathrm{CFU} / \mathrm{g}\right)$, served as E. faecium group. The three groups were housed individually in stainless steel metabolic cages $\left(1.20 \times 1.10 \mathrm{~m}^{2}\right)$ and maintained in an environmentally controlled room $\left(25^{\circ} \mathrm{C}\right)$ by air conditioning. During a 4-day adaptation period, all piglets had free access to the basal diet to help them adapt to solid food. The day on which the basal diet supplemented with $E$. faecium R1 was fed was designated as day 1 ( 25 days of age). E. faecium R1 (powder) which was prepared by the freeze-drying method was thoroughly mixed with basal diet (the final concentration of $6.5 \times 10^{6} \mathrm{CFU} / \mathrm{g}$ E. faecium R1) before each feeding. The dosage of $6.5 \times 10^{6} \mathrm{CFU} / \mathrm{g}$ E. faecium R1 was chosen because we found that dietary supplementation with E. faecium R1 ( $\geq 6.5 \times 10^{6} \mathrm{CFU} / \mathrm{g}$ ) could improve the growth performance of piglets in pre-experiment. The corn and soybean meal-based diet (Table 1) was formulated to meet National Research Council's (NRC, 2012) recommended requirements for all nutrients [24]. The content of calcium (Ca), total phosphorus $(\mathrm{P})$, and crude protein $(\mathrm{CP})$ in dietary was analyzed according to the Weende method of the feed proximate analysis as described by Henneberg and Stohmann [24]. The content of tryptophan, cystine, methionine, threonine, and total lysine in diets was analyzed by an automatic amino acids analyzer (S433D, Sykam GmbH, Eresing, Germany) [24]. 
Table 1. Ingredients and contents of energy and nutrients of the basal diet.

\begin{tabular}{|c|c|}
\hline Ingredients & Content $(\%)$ \\
\hline Corn (DE 14.27 MJ / kg, CP 8.7\%) & 61.88 \\
\hline Soybean meal 1 (DE $13.5 \mathrm{MJ} / \mathrm{kg}, \mathrm{CP} 40 \%$ ) & 21.98 \\
\hline Wheat Middling (DE $13.4 \mathrm{MJ} / \mathrm{kg}, \mathrm{CP} 13 \%$ ) & 4.00 \\
\hline Dried whey (CP 12\%) & 3.00 \\
\hline Fish meal (CP 66\%) & 3.00 \\
\hline Soy protein concentrate (CP $65 \%)$ & 1.50 \\
\hline $\mathrm{CaHPO} 4$ & 1.25 \\
\hline Premix ${ }^{+}$ & 1.00 \\
\hline Limestone $(\mathrm{CaCO} 3>35 \%)$ & 0.69 \\
\hline $\mathrm{NaCl}$ & 0.30 \\
\hline Acidifier (Citric acid > 99\%) & 0.30 \\
\hline Soybean oil & 0.50 \\
\hline L-Lysine $\mathrm{HCl}$ (78.8\% lysine) & 0.25 \\
\hline Choline chloride & 0.20 \\
\hline Mold inhibitor (Calcium propionate $>30 \%$ ) & 0.10 \\
\hline DL-Methionine $(99 \%$ methionine & 0.05 \\
\hline Nutrients composition & \\
\hline Digestible energy $\ddagger(\mathrm{MJ} / \mathrm{kg})$ & 14.22 \\
\hline Crude protein $(\%) \S$ & 20.9 \\
\hline Total threonine $(\%) \S$ & 0.74 \\
\hline Total methionine $(\%) \S$ & 0.30 \\
\hline Total lysine $(\%) \S$ & 1.15 \\
\hline Total tryptophan $(\%) \S$ & 0.21 \\
\hline Total calcium $(\%) \S$ & 0.70 \\
\hline Total phosphorus (\%) $\S$ & 0.60 \\
\hline Available phosphorus (\%) $\ddagger$ & 0.32 \\
\hline
\end{tabular}

${ }^{\dagger}$ Premix provided the following amounts of vitamins and trace minerals per kilogram of the complete diet: ferrum, $100 \mathrm{mg}\left(\mathrm{FeSO}_{4} \cdot \mathrm{H}_{2} \mathrm{O}\right)$; copper, $150 \mathrm{mg}\left(\mathrm{CuSO}_{4} \cdot 5 \mathrm{H}_{2} \mathrm{O}\right)$; manganese, $40 \mathrm{mg}\left(\mathrm{MnSO}_{4} \cdot 5 \mathrm{H}_{2} \mathrm{O}\right)$; zinc, $100 \mathrm{mg}$ $\left(\mathrm{ZnSO}_{4} \cdot 7 \mathrm{H}_{2} \mathrm{O}\right)$; iodine, $0.5 \mathrm{mg}(\mathrm{KI})$; selenium, $0.3 \mathrm{mg}\left(\mathrm{Na}_{2} \mathrm{SeO}_{3} \cdot 5 \mathrm{H}_{2} \mathrm{O}\right)$; vitamin A acetate, $3.66 \mathrm{mg}$; cholecalciferol, $0.10 \mathrm{mg}$; DL- $\alpha$-tocopheryl acetate, $36.4 \mathrm{mg}$; menadione, $4 \mathrm{mg}$; thiamin, $6 \mathrm{mg}$; riboflavin, $12 \mathrm{mg}$; pyridoxine, $6 \mathrm{mg}$; cyanocobalamin, $0.05 \mathrm{mg}$; biotin, $0.2 \mathrm{mg}$; folic acid, $2 \mathrm{mg}$; niacin, $50 \mathrm{mg}$; D-calcium pantothenate, $25 \mathrm{mg}$; $\ddagger$ Calculated value; $§$ Analyzed value.

During days 1-21 of the trial prior to the LPS challenge, the body weight, feed intake, and diarrhea of piglets were recorded to statistically analyze their growth performance. Piglets were weighed once a week and the feed intake was recorded daily. To determine the diarrhea rate, individual pigs were examined for diarrhea four times per day. Diarrhea was quantified by the following equation for each pig. Diarrhea rate $(\%)=$ total diarrhea incidences $/ 8 \times 100$. Average daily gain $(\mathrm{Kg} /$ day $)=$ gain $(\mathrm{Kg}) / 21$. Average daily fed intake $(\mathrm{Kg} /$ day $)=$ total feed intake $(\mathrm{Kg}) / 21$. Feed/gain ratio $(\%)=$ total feed intake $(\mathrm{Kg}) /$ gain $(\mathrm{Kg}) \times 100$.

On day 21, the LPS group and E. faecium group were injected intraperitoneally with LPS (100 $\mu \mathrm{g} / \mathrm{kg}$ bodyweight) (Escherichia coli serotype O55: B5; Sigma) dissolved in sterile saline. The control group was injected with the same volume of sterile saline. At $3 \mathrm{~h}$ post LPS challenge, blood samples were collected from the anterior vena cava into heparinized vacuum tubes and centrifuged at $1000 \times \mathrm{g}$ for $10 \mathrm{~min}$ at $4{ }^{\circ} \mathrm{C}$, and then the separated blood plasma was divided into sterile tubes and stored at $-80^{\circ} \mathrm{C}$ for further analysis. At $6 \mathrm{~h}$ post LPS challenge, all piglets were euthanized by deep anesthesia with pentobarbital sodium ( $50 \mathrm{mg} / \mathrm{kg}$ bodyweight). Subsequently, the liver and pancreas were collected from the pig abdomen and then immediately stored at $-80{ }^{\circ} \mathrm{C}$ until assay. Four $10 \mathrm{~cm}$ intestinal segments were respectively cut off from duodenum, jejunum, ileum, and colon and then gently flushed with ice-cold $0.9 \%$ saline. Subsequently, intestinal mucosae were scraped off from the intestinal segments and immediately frozen in liquid nitrogen. All samples were collected within $15 \mathrm{~min}$ after killing and stored at $-80{ }^{\circ} \mathrm{C}$ for further analysis. 


\subsection{Biochemical Indices in Plasma and Liver}

The blood plasma was taken out from the $-80{ }^{\circ} \mathrm{C}$ ultra-low temperature refrigerator and placed at $4{ }^{\circ} \mathrm{C}$ until it melts. The liver tissue $(\sim 200 \mathrm{mg})$ was homogenized in a ninefold volume of freezing saline and then centrifuged at $2500 \mathrm{rpm}$ for $10 \mathrm{~min}$ at $4{ }^{\circ} \mathrm{C}$ to obtain the supernatant fluid used for assays. Insulin (INS), cortisol (COR), glucagon (GC), prostaglandin 2 (PGE2), interleukin-1 $\beta$ (IL-1 $\beta$ ), insulin-like growth factor 1 (IGF-1) in the plasma, and IGF-1, PGE2, and IL-1 $\beta$ in the liver were determined using commercially available PGE2 (HY-10047) RIA kit purchased from Beijing Huaying Institute of Biology and Insulin (KAP1251) assay kit, COR (KAPDB280) assay kit, GC (RV07-152101) assay kit, IL-1 $\beta$ (KAP1211) assay kit and IGF-1 (KAP1581) assay kit purchased from Beijing North Institute of Biology [24,25]. The assays were performed in triplicate.

\subsection{Determination of Antioxidant Capacity and Oxidation-Related Product}

Plasma and liver samples were analyzed for the activities of ant-oxidative enzymes and related products. Catalase (CAT), myeloperoxidase (MPO), total nitric oxide synthase (tNOS), inducible nitric oxide synthase (iNOS), glutathione peroxidase (GSH-Px), and malondialdehyde (MDA) were determined using commercially available catalase (A0072-1) assay kit (Ultraviolet), myeloperoxidase (A044-1-1)assay kit, nitric oxide synthase (NOS) typed assay kit (Colorimetric method), glutathione peroxidase (GSH-PX) assay kit and malondialdehyde (MDA) assay kit (TBA method) purchased from Nanjing Jiancheng Bioengineering Institute [24,26]. The assays were performed in triplicate.

\subsection{Determination of Intestinal Absorption Function and Disaccharidase Activity}

The activities of intestinal disaccharidases (lactase, sucrase, and maltase) determined using glucose kits (Cat. A082-1, A082-2, and A082-3 for lactase, sucrase, and maltase, respectively), were analyzed as previously described [27]. D-Xylose in plasma was determined as described by Yi et al. [27]. The concentration of D-xylose in plasma were determined using commercially available kits (Cat. A035-1-1) purchased from Nanjing Jiancheng Bioengineering Institute. The assays were performed in triplicate.

\subsection{Quantitative PCR ( $q P C R$ ) for Gene Expression Analyses}

Total RNA was isolated from approximately $100 \mathrm{mg}$ of each frozen intestinal sample as previously described [25]. The qualified RNA was reverse-transcribed to cDNA for qPCR as previously described [26]. The primers [27] were designed according to the genomic sequence of the pig. Ribosomal protein L4 (RPL4) and glyceraldehyde-3-phosphate dehydrogenase (GADPH) were used as internal control genes. Each biological sample was run in triplicate.

\section{Statistical Analysis}

Data are expressed as means \pm SD and analyzed by one-way analysis ANOVA in the SPSS 16.0 software (Chicago, IL, USA). Differences among treatment means were determined by Duncan's multiple comparison test. Additionally, the difference in the means of growth performance was determined by the Student's paired $t$-test. $P<0.05$ was taken to indicate statistical significance [26,27].

\section{Results}

\subsection{Biological Characteristics of E. faecium R1}

In this study, ten strains of probiotics (E. faecium R 1, E. faecium R2, Bacillus subtilis (B. subts), Lactobacillus casei Q (L. casei Q), L. casei G, Probiotic G-Q, Probiotic G-G, Lactobacillus Bacillus (L. Bacillus), Lactobacillus acidophilus (L. acidophilus), and Enterococcus lactis (E. lactis)) were isolated and identified successfully. E. faecium R 1, E. faecium R2, and E. lactis belong to Enterococcus genus. B. Subts belong to Bacillus genus. L. casei Q, L. casei G, L. acidophilus and L. Bacillus belong to the Lactobacillus genus. Probiotic G-Q and Probiotic G-G belong to Bifidobacterium genus. The inhibitory effects of ten probiotic strains to E. coli K88 in vitro 
are shown in Table 2. These results showed that all ten probiotic strains have bacteriostatic properties against E. coli K88, of which E. lactis, E. faecium R1, E. faecium R2, and Probiotic G-G exhibited excellent antibacterial activity against E. coli K88. The diameters of the inhibition zone were 18.21, 17.94, 17.53, and $17.34 \mathrm{~mm}$, respectively.

Table 2. Analysis of bacteriostasis and heat resistance of probiotics.

\begin{tabular}{ccc}
\hline Strains & Diameters of the Inhibition Zone $(\mathbf{m m})$ & Survival Rate $\left(\mathbf{6 0} \mathbf{\circ}^{\circ} \mathbf{C}\right)$ \\
\hline R1 & 17.94 & 86.78 \\
R2 & 17.53 & 17.88 \\
R3 & 14.32 & \\
R4 & 16.68 & \\
R5 & 16.12 & \\
R6 & 15.98 & \\
R7 & 17.34 & \\
R8 & 16.21 & \\
R9 & 16.52 & 19.77 \\
R10 & 18.21 & \\
\hline
\end{tabular}

R1 = E. faecium R1; R2 = E. faecium R2; R3 = B. subtilis; R4 = L. casei Q; R5 = L. casei $\mathrm{G} ; \mathrm{R} 6$ = Probiotic G-Q; R7 = Probiotic G-G; R8 = L. Bacillus; R9 = L. acidophilus; R10 = E. lactis.

Subsequently, the tolerances of E. lactis, E. faecium R1, E. faecium R2, and Probiotic G-G to acid, bile salt, and the high temperature were tested, respectively. The acid tolerances of these four strains are shown in Figure 1A. After incubation in an acidic environment $(\mathrm{pH}=1.5,2.5$, or 3.5$)$ for $3 \mathrm{~h}$ at $37^{\circ} \mathrm{C}$, the survival rates of E. faecium $\mathrm{R} 1$ and E. lactis were significantly higher than those of E. faecium R2 and Probiotic G-G. The tolerances of these four strains to bile salt showed a great difference (Figure 1B). After incubation in PBS with $0.1,0.3$ or $0.5 \%$ bile salt for $3 \mathrm{~h}$ at $37^{\circ} \mathrm{C}$, the survival rates of E. faecium R1 and E. lactis were significantly higher than those of E. faecium R2 and Probiotic G-G, and the survival rate of E. faecium R1 was significantly higher than that of Probiotic G-G. After incubation in a water bath at $60^{\circ} \mathrm{C}, 75^{\circ} \mathrm{C}$ or $90^{\circ} \mathrm{C}$ for $10 \mathrm{~min}$, the survival rates of all these four strains were less than $1 \%$ at $75^{\circ} \mathrm{C}$ and $90^{\circ} \mathrm{C}$ (data not shown). When the temperature was $60^{\circ} \mathrm{C}$, the survival rate of E. faecium R1 $(86.78 \%)$ was the highest among these four strains and the number of viable $E$. faecium $\mathrm{R} 1\left(7.81 \times 10^{7} \mathrm{CFU} / \mathrm{mL}\right)$ was significantly more than those of E. faecium R2 $\left(1.52 \times 10^{7} \mathrm{CFU} / \mathrm{mL}\right)$, Probiotic G-G $\left(7.81 \times 10^{7} \mathrm{CFU} / \mathrm{mL}\right)$, and E. lactis $\left(3.50 \times 10^{7} \mathrm{CFU} / \mathrm{mL}\right)($ Table 2).

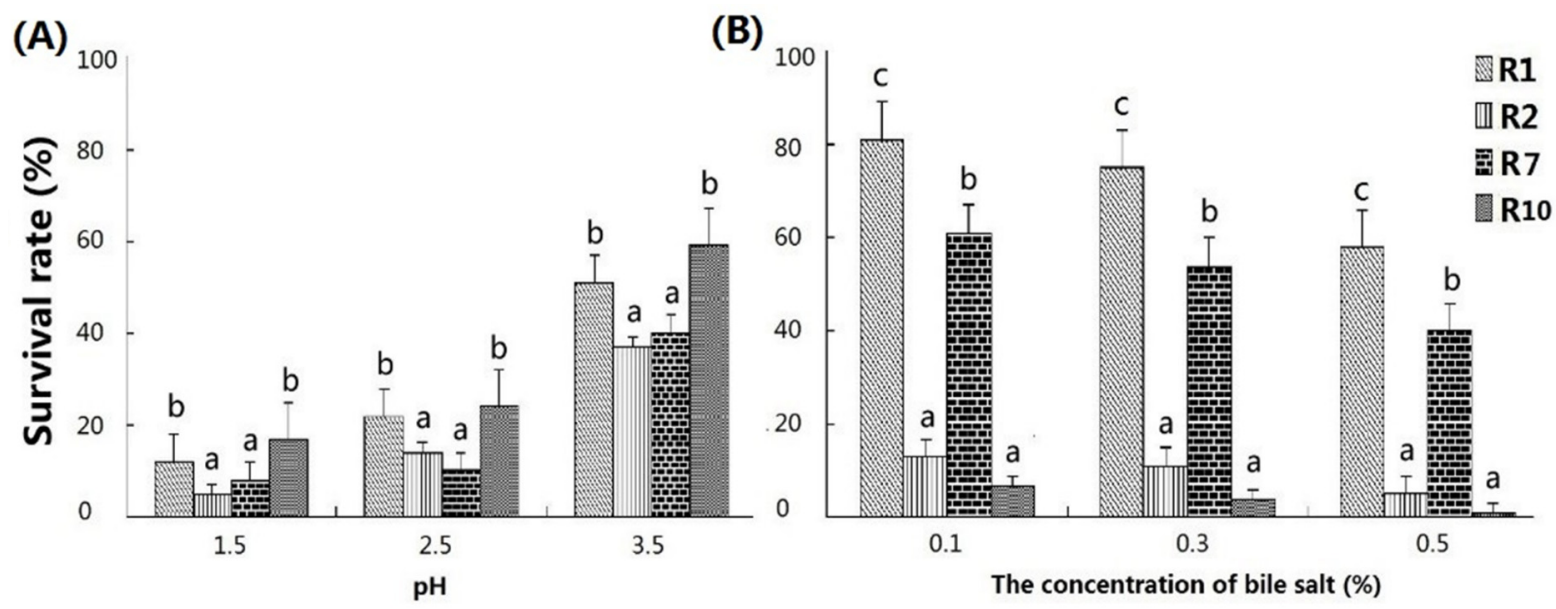

Figure 1. Analysis of acid and bile salt tolerances of 4 probiotic strains (R1, R2, R7, and R10). (A) Survival rates of R1, R2, R7 and $\mathrm{R} 10$ in acid ( $\mathrm{pH}=1.5,2.5$ or 3.5) condition, respectively; (B) Survival rates of R1, R2, R7 and R10 in $0.1 \%, 0.3 \%$ and $0.5 \%$ bile salt medium, respectively. R1 = E. faecium R1; R2 = E. faecium R2; R7 = Probiotic G-G; R10 = E. lactis. a,b,c Within a group, means with different superscripts differ $(p<0.05)$. 


\subsection{The Growth Performance of Piglets}

Prior to the LPS challenge, no significant difference in average daily gain (ADG) of piglets in the E. faecium group compared with that in the control group was found. During days $15-21$, the feed to gain $(\mathrm{F} / \mathrm{G})$ ratio of piglets in the E. faecium group was significantly decreased compared with that in the control group. During days 0-21, the diarrhea rate (DR) of piglets in the E. faecium group was significantly lower than that in the control group. DR of piglets in the E. faecium group decreased by $45.96 \%$ compared with that in the control group (Table 3).

Table 3. Effects of dietary supplementation with E. faecium R1 on growth performance of weaned piglets prior to LPS challenge.

\begin{tabular}{cccc}
\hline Items & Day & Control Group & E. faecium Group \\
\hline \multirow{2}{*}{ ADG (Kg/day) } & $0-14$ & $0.23 \pm 0.07$ & $0.24 \pm 0.07$ \\
& $15-21$ & $0.36 \pm 0.10$ & $0.38 \pm 0.14$ \\
& $0-21$ & $0.27 \pm 0.07$ & $0.29 \pm 0.07$ \\
ADFI (Kg/day) & $0-14$ & $0.30 \pm 0.06$ & $0.33 \pm 0.04$ \\
& $15-21$ & $0.63 \pm 0.02$ & $0.63 \pm 0.04$ \\
& $0-21$ & $0.41 \pm 0.04$ & $0.43 \pm 0.03$ \\
\hline F/G ratio & $0-14$ & $1.41 \pm 0.14$ & $1.31 \pm 0.10$ \\
& $15-21$ & $1.78 \pm 0.03^{\mathrm{b}}$ & $1.41 \pm 0.09^{\mathrm{a}}$ \\
\hline Diarrhea rate (\%) & $0-21$ & $1.57 \pm 0.21$ & $4.95 \pm 0.93^{\mathrm{a}}$
\end{tabular}

Data are means $\pm \mathrm{SD}, n=8$ for the control group and $n=8$ for the E. faecium group. ${ }^{\mathrm{a}, \mathrm{b}}$ Within a row, means with different superscripts differ $(p<0.05)$.ADG = average daily gain; ADFI = average daily fed intake; F/G = feed/gain ratio. Control group $=$ weaned piglets fed the basal diet; E. faecium group = weaned piglets fed the basal diet supplemented with $6.5 \times 10^{6} \mathrm{CFU} / \mathrm{g}$ E. faecium $\mathrm{R} 1$.

\subsection{Plasma Biochemical Parameters}

Thirteen plasma biochemical indicators are determined and shown in Table 4. After the LPS challenge, plasma AST activity and the concentration of plasma TBIL in the piglets in the LPS group were significantly increased compared with those in the control group. In contrast, plasma AST activity in piglets in the E. faecium group was significantly decreased compared with that in the LPS group. No significant difference was found in the plasma AST activity in piglets between the E. faecium group and the control group. However, the concentration of plasma TBIL in the piglets in the E. faecium group did not differ from that in the LPS group. No significant differences were found in other indices.

Table 4. Effects of dietary supplementation with E. faecium R1 on plasma biochemical parameters of weaned pigs after LPS challenge.

\begin{tabular}{|c|c|c|c|}
\hline Items & Control Group & LPS Group & E. faecium Group \\
\hline $\operatorname{ALT}(\mathrm{U} / \mathrm{L})$ & $42.8 \pm 9.4$ & $44.0 \pm 14.8$ & $39.7 \pm 14.4$ \\
\hline AST (U/L) & $41.7 \pm 13.2^{\mathrm{a}}$ & $58.8 \pm 9.5^{b}$ & $48.0 \pm 8.4^{\mathrm{a}}$ \\
\hline TBIL $(\mu \mathrm{mol} / \mathrm{L})$ & $4.4 \pm 0.8^{\mathrm{a}}$ & $8.2 \pm 1.1^{b}$ & $8.7 \pm 1.7^{b}$ \\
\hline $\mathrm{TP}(\mathrm{g} / \mathrm{L})$ & $48.7 \pm 3.3$ & $46.7 \pm 6.1$ & $46.2 \pm 3.7$ \\
\hline $\operatorname{ALB}(\mathrm{g} / \mathrm{L})$ & $27.0 \pm 4.1$ & $25.6 \pm 4.6$ & $26.4 \pm 2.0$ \\
\hline $\mathrm{CHOL}(\mu \mathrm{mol} / \mathrm{L})$ & $1.83 \pm 0.24$ & $1.84 \pm 0.50$ & $1.69 \pm 0.38$ \\
\hline $\mathrm{TG}(\mathrm{mmol} / \mathrm{L})$ & $0.38 \pm 0.13$ & $0.63 \pm 0.42$ & $0.65 \pm 0.40$ \\
\hline BUN (mmol/L) & $2.72 \pm 0.85$ & $3.39 \pm 1.86$ & $2.98 \pm 1.08$ \\
\hline $\operatorname{ALP}(\mathrm{U} / \mathrm{L})$ & $270.5 \pm 53.2$ & $343.3 \pm 95.7$ & $304.1 \pm 81.0$ \\
\hline Crea $(\mu \mathrm{mol} / \mathrm{L})$ & $86 \pm 9$ & $108 \pm 24$ & $100 \pm 28$ \\
\hline GLU (mmol/L) & $5.95 \pm 0.94$ & $5.14 \pm 1.82$ & $4.39 \pm 1.42$ \\
\hline $\mathrm{CL}(\mathrm{mmol} / \mathrm{L})$ & $107 \pm 2$ & $107 \pm 2$ & $108 \pm 2$ \\
\hline GGT (U/L) & $35.4 \pm 6.7$ & $45.3 \pm 39.4$ & $51.6 \pm 25.6$ \\
\hline
\end{tabular}

Data are means $\pm \mathrm{SD}, n=8$ for the control group, $n=8$ for the LPS (lipopolysaccharide) group and $n=8$ for the $E$. faecium group. ${ }^{\mathrm{a}, \mathrm{b}}$ Within a row, means with different superscripts differ $(p<0.05)$. ALT = alanine aminotransferase; $\mathrm{AST}=$ aspartate aminotransferase; $\mathrm{TBIL}=$ total bilirubin; $\mathrm{TP}=$ total protein; $\mathrm{ALB}=$ albumin; $\mathrm{CHOL}=$ total cholesterol ;TG = triglyceride; BUN = blood urine nitrogen; ALP = alkaline phosphatase; Crea = creatinine; GLU $=$ glucose $; \mathrm{CL}=$ chlorine; $\mathrm{GGT}=\gamma$-glutamyltransferase . 


\subsection{The Concentrations of Inflammatory Mediators and Hormones in Plasma}

Six plasma and three liver indices of inflammatory mediators and hormones are determined and shown in Table 5. After the LPS challenge, the concentrations of COR and IGF-1 in the plasma of piglets in the LPS group were significantly higher than those in the control group. The concentrations of plasma COR and liver IL-1 $\beta$ in the piglets in the $E$. faecium group were significantly higher than those in the LPS group. The concentration of plasma GC in the piglets in the E. faecium group was significantly higher than that in the control group. The concentration of PGE2 in the liver of piglets in the E. faecium group was significantly decreased compared with that in the LPS group. No significant differences were found in other indices.

Table 5. Effects of dietary supplementation with E. faecium R1 on IL-1 $\beta$ and hormones in plasma and liver of weaned pigs after LPS challenge.

\begin{tabular}{|c|c|c|c|}
\hline Items & Control Group & LPS Group & E. faecium Group \\
\hline \multicolumn{4}{|l|}{ Plasma } \\
\hline COR (ng/mL) & $53.12 \pm 16.38^{\mathrm{a}}$ & $140.18 \pm 80.30^{b}$ & $221.20 \pm 39.85^{c}$ \\
\hline $\mathrm{GC}(\mu \mathrm{IU} / \mathrm{mL})$ & $154.09 \pm 64.72^{\mathrm{a}}$ & $287.62 \pm 150.04^{\mathrm{a}, \mathrm{b}}$ & $316.24 \pm 195.61^{b}$ \\
\hline INS $(\mu \mathrm{IU} / \mathrm{mL})$ & $5.57 \pm 2.23$ & $4.64 \pm 3.61$ & $7.16 \pm 4.65$ \\
\hline IGF-1 (ng/mL) & $256.85 \pm 91.04^{\mathrm{a}}$ & $346.45 \pm 47.38^{b}$ & $304.01 \pm 75.11^{\mathrm{a}, \mathrm{b}}$ \\
\hline PGE2 (pg/mL) & $29.31 \pm 3.09^{\mathrm{a}}$ & $30.04 \pm 2.40^{\mathrm{a}}$ & $30.70 \pm 3.19^{a}$ \\
\hline IL-1 $\beta(\mathrm{pg} / \mathrm{mL})$ & $0.05 \pm 0.02$ & $0.06 \pm 0.03$ & $0.06 \pm 0.03$ \\
\hline \multicolumn{4}{|l|}{ Liver } \\
\hline IGF-1 (ng/mg wet weight) & $133.79 \pm 34.41$ & $156.12 \pm 33.28$ & $153.71 \pm 25.21$ \\
\hline $\mathrm{PGE}_{2}$ (pg/mg wet weight) & $2.01 \pm 0.35^{\mathrm{b}}$ & $1.90 \pm 0.27^{b}$ & $1.47 \pm 0.19^{\mathrm{a}}$ \\
\hline IL-1 $\beta$ (pg/mg wet weight) & $0.29 \pm 0.07^{\mathrm{a}}$ & $0.35 \pm 0.07^{\mathrm{a}}$ & $0.44 \pm 0.10^{b}$ \\
\hline
\end{tabular}

Data are means $\pm \mathrm{SD}, n=8$ for the control group, $n=8$ for the LPS (lipopolysaccharide) group and $n=8$ for the $E$. faecium group. ${ }^{\mathrm{a}, \mathrm{b}}$ Within a row, means with different superscripts differ $(p<0.05)$.COR $=$ Cortisol; GC $=$ glucagon; INS = insulin; IGF-1 = insulin-like growth factor 1; PGE $2=$ prostaglandin (PG) E2; IL-1 $\beta=$ interleukin-1 beta.

\subsection{Anti-Oxidative Enzymes and Oxidation Products in the Plasma, Liver, and Pancreas}

The parameters which are related to anti-oxidative enzymes and oxidation products in this study are shown in Table 6. After the LPS challenge, CAT activity in the pancreas of piglets in the LPS group was significantly decreased compared with that in the control group. Plasma MPO activity in the piglets in the LPS group was significantly increased compared with that in the control group. Dietary supplementation with E. faecium R1 significantly increased CAT activity in the pancreas, and significantly decreased total nitric oxide synthase (tNOS) activity in the pancreas and the content of MDA in the liver of piglets in E. faecium group compared with that in the LPS group.

Table 6. Effects of dietary supplementation with E. faecium R1 on the redox status of weaned piglets.

\begin{tabular}{cccc}
\hline Items & Control Group & LPS Group & E. faecium Group \\
\hline CAT & & & \\
Plasma (U/mL) & $2.68 \pm 1.21$ & $2.87 \pm 1.08$ & $2.82 \pm 1.50$ \\
Pancreas (U/mg protein) & $15.01 \pm 1.44^{\mathrm{b}}$ & $12.78 \pm 1.28^{\mathrm{a}}$ & $17.08 \pm 1.72^{\mathrm{b}}$ \\
Duodenum (U/mg protein) & $1.63 \pm 0.51$ & $1.42 \pm 0.39$ & $1.26 \pm 0.29$ \\
Ileum (U/mg protein) & $9.52 \pm 1.20$ & $9.08 \pm 2.93$ & $8.51 \pm 2.94$ \\
GSH-Px & & & \\
Plasma (U/mL) & $354.45 \pm 53.79$ & $336.94 \pm 77.93$ & $332.11 \pm 37.45$ \\
Pancreas (U/mg protein) & $124.32 \pm 20.15$ & $124.80 \pm 14.56$ & $125.59 \pm 19.98$ \\
Duodenum (U/mg protein) & $29.56 \pm 6.17$ & $29.20 \pm 5.87$ & $30.02 \pm 6.68$ \\
Ileum (U/mg protein) & $65.46 \pm 12.92$ & $69.15 \pm 14.03$ & $56.50 \pm 9.38$ \\
tNOS & & & \\
Plasma (U/mL) & $20.34 \pm 1.45$ & $20.58 \pm 5.20$ & $17.30 \pm 2.46$ \\
Pancreas (U/mg protein) & $17.74 \pm 1.38{ }^{\mathrm{a}}$ & $17.09 \pm 1.90 \mathrm{a}$ & $14.91 \pm 1.10^{\mathrm{b}}$ \\
Duodenum (U/mg protein) & $8.32 \pm 1.07$ & $7.53 \pm 0.66$ & $7.99 \pm 2.09$ \\
Ileum (U/mg protein) & $8.62 \pm 2.24$ & $8.35 \pm 2.05$ & $7.92 \pm 2.00$ \\
Colon (U/mg protein) & $10.16 \pm 2.56$ & $7.90 \pm 0.97$ & $9.64 \pm 6.02$ \\
\hline
\end{tabular}


Table 6. Cont.

\begin{tabular}{cccc}
\hline Items & Control Group & LPS Group & E. faecium Group \\
\hline iNOS & & & \\
Plasma (U/mL) & $4.90 \pm 1.58$ & $4.92 \pm 1.48$ & $4.31 \pm 2.24$ \\
Liver (U/mg protein) & $3.19 \pm 1.75$ & $2.84 \pm 0.93$ & $3.43 \pm 1.34$ \\
Jejunum (U/mg protein) & $4.25 \pm 1.53$ & $3.57 \pm 1.26$ & $4.97 \pm 1.18$ \\
Colon (U/mg protein) & $3.71 \pm 1.40$ & $3.13 \pm 0.83$ & $4.65 \pm 2.11$ \\
MPO & & & \\
Plasma (U/mL) & $32.78 \pm 3.82^{\mathrm{a}}$ & $44.74 \pm 3.23^{\mathrm{b}}$ & $38.89 \pm 3.45^{\mathrm{a}}$ \\
Liver (U/mg protein) & $0.33 \pm 0.30$ & $0.18 \pm 0.04$ & $0.35 \pm 0.17$ \\
Pancreas (U/mg protein) & $0.23 \pm 0.08$ & $0.18 \pm 0.10$ & $0.19 \pm 0.07$ \\
Duodenum (U/mg protein) & $0.20 \pm 0.10$ & $0.23 \pm 0.07$ & $0.23 \pm 0.08$ \\
Jejunum (U/mg protein) & $0.21 \pm 0.12$ & $0.29 \pm 0.09$ & $0.35 \pm 0.20$ \\
Colon (U/mg protein) & $0.21 \pm 0.12$ & $0.23 \pm 0.13$ & $0.27 \pm 0.10$ \\
MDA & & & \\
Plasma (nmol/mL) & $3.75 \pm 1.00$ & $3.55 \pm 0.42$ & $4.50 \pm 1.21$ \\
Liver (nmol/mg protein) & $8.46 \pm 1.40^{\mathrm{a}}$ & $7.81 \pm 1.64 \mathrm{a}$ & $5.80 \pm 1.25^{\mathrm{b}}$ \\
Pancreas (nmol/mg protein) & $1.26 \pm 0.34$ & $1.21 \pm 0.57$ & $1.43 \pm 0.41$ \\
duodenum (nmol/mg & $3.33 \pm 1.24$ & $3.20 \pm 0.82$ & $3.20 \pm 1.09$ \\
protein) & $2.41 \pm 0.73$ & $2.21 \pm 0.95$ & $2.43 \pm 1.54$ \\
Jejunum (nmol/mg protein) & $2.32 \pm 0.37$ & $3.58 \pm 1.42$ & $2.56 \pm 1.60$ \\
Ileum ( $\mu$ g /g protein) & $5.95 \pm 2.27$ & $5.44 \pm 1.45$ & $3.92 \pm 1.83$ \\
Colon (nmol/mg protein) &
\end{tabular}

Data are means $\pm \mathrm{SD}, n=8$ for the control group, $n=8$ for the LPS (lipopolysaccharide) group, and $n=8$ for the $E$. faecium group. All data are expressed as means $\pm \mathrm{SD}$ and analyzed by one-way analysis of variance. Differences among treatment means were determined by Duncan's post hoc test. ${ }^{\mathrm{a}, \mathrm{b}}$ Within a row, means with different superscripts differ $(p<0.05)$. CAT = catalase; GSH-Px = glutathione peroxidase; $\mathrm{tNOS}=$ total nitric oxide synthase; iNOS = inducible nitric oxide synthase; $\mathrm{MPO}=$ myeloperoxidase; $\mathrm{MDA}=$ malondialdehyde .

\subsection{Effects of E. faecium R1 on Intestinal Function in the Piglets Challenged with LPS}

Indicators related to intestinal absorption function in piglets are shown in Table 7. The contents of plasma D-Xylose and alkaline phosphatase (AKP), lactase, and sucrase were significantly decreased compared with those in the control group. However, compared with the LPS group, dietary supplementation with E. faecium R1 tended to increase $(p<0.1)$ the contents of lactase and sucrase in the jejunum of piglets.

Table 7. Effects of dietary supplementation with E. faecium R1 on the intestinal digestive and absorption function in weaned piglets.

\begin{tabular}{|c|c|c|c|}
\hline Items & Control Group & LPS Group & E. faecium Group \\
\hline \multicolumn{4}{|c|}{ D-xylose (mmol/L) } \\
\hline plasma & $1.53 \pm 0.34^{b}$ & $0.84 \pm 0.60^{\mathrm{a}}$ & $0.79 \pm 0.47^{\mathrm{a}}$ \\
\hline \multicolumn{4}{|c|}{ AKP (U/mg protein) } \\
\hline Duodenum & $71.51 \pm 22.20^{b}$ & $61.39 \pm 24.81^{\mathrm{a}, \mathrm{b}}$ & $43.92 \pm 15.32^{\mathrm{a}}$ \\
\hline Jejunum & $82.13 \pm 37.10^{b}$ & $49.68 \pm 25.09^{a}$ & $46.41 \pm 26.51^{a}$ \\
\hline Ileum & $90.68 \pm 40.07$ & $70.47 \pm 41.94$ & $55.54 \pm 20.58$ \\
\hline Colon & $2.87 \pm 1.10$ & $3.72 \pm 2.12$ & $3.64 \pm 0.93$ \\
\hline \multicolumn{4}{|c|}{ Maltase (U/mg protein) } \\
\hline Jejunum & $739.87 \pm 313.91$ & $588.03 \pm 291.51$ & $535.56 \pm 281.23$ \\
\hline Ileum & $1098.62 \pm 507.26$ & $790.51 \pm 520.02$ & $632.89 \pm 446.26$ \\
\hline Colon & $138.61 \pm 35.43$ & $132.24 \pm 34.38$ & $113.51 \pm 39.03$ \\
\hline \multicolumn{4}{|c|}{ Lactase (U/mg protein) } \\
\hline Duodenum & $161.86 \pm 99.47$ & $144.94 \pm 83.05$ & $106.33 \pm 64.23$ \\
\hline Jejunum & $271.86 \pm 172.24^{b}$ & $109.52 \pm 55.77^{a}$ & $159.36 \pm 116.13^{a, b}$ \\
\hline Ileum & $30.48 \pm 12.05$ & $24.73 \pm 14.40$ & $18.67 \pm 5.75$ \\
\hline Colon & $36.75 \pm 8.78^{b}$ & $33.45 \pm 8.78^{a, b}$ & $25.13 \pm 11.86^{a}$ \\
\hline \multicolumn{4}{|c|}{ Sucrase (U/mg protein) } \\
\hline Duodenum & $70.19 \pm 42.92$ & $50.30 \pm 44.96$ & $34.33 \pm 31.51$ \\
\hline Jejunum & $471.79 \pm 290.61^{b}$ & $175.69 \pm 140.78^{a}$ & $229.16 \pm 211.64^{a}$ \\
\hline Ileum & $150.25 \pm 75.42$ & $117.55 \pm 114.16$ & $81.12 \pm 64.20$ \\
\hline
\end{tabular}

Values are mean \pm SD, $n=8$ for the control group, $n=8$ for the LPS (lipopolysaccharide) group and $n=8$ for the E. faecium group. ${ }^{\mathrm{a}, \mathrm{b}}$ Within a row, means with different superscripts differ $(p<0.05)$. 


\subsection{The mRNA Levels of Villin, Bal- $x L$, and $p B D-1$ in the Small Intestine}

The mRNA levels of villin in jejunum and ileum in piglets in the LPS group were significantly decreased compared with that in the control group. Compared with the LPS group, dietary supplementation with E. faecium R1 significantly increased the mRNA levels of villin in the jejunum and ileum in piglets. Meanwhile, the mRNA levels of $p B D-1$ and $B a l-x L$ in the ileum of piglets in the E. faecium group were significantly increased compared with those in the LPS group (Table 8).

Table 8. Effects of dietary supplementation with E. faecium R1 on mRNA expression of villin, Bcl- $x 1$, and $p B D-1$ in Jejunum or Ileum of weaned piglets after LPS challenge.

\begin{tabular}{cccc}
\hline Items & Control Group & LPS Group & E. faecium Group \\
\hline Villin & & & \\
Jejunum & $1.000 \pm 0.226^{\mathrm{a}}$ & $0.660 \pm 0.165^{\mathrm{b}}$ & $1.108 \pm 0.230^{\mathrm{a}}$ \\
Ileum & $1.000 \pm 0.160^{\mathrm{a}}$ & $0.630 \pm 0.136^{\mathrm{b}}$ & $1.067 \pm 0.136^{\mathrm{a}}$ \\
Bcl-x1 & $1.000 \pm 0.168^{\mathrm{b}}$ & $0.928 \pm 0.195^{\mathrm{b}}$ & $1.601 \pm 0.382^{\mathrm{a}}$ \\
Ileum & $1.000 \pm 0.239^{\mathrm{b}}$ & $1.371 \pm 0.356^{\mathrm{b}}$ & $3.079 \pm 0.620^{\mathrm{a}}$ \\
pBD-1 & & & \\
Ileum & & &
\end{tabular}

Data are means $\pm \mathrm{SD}, n=8$ for the control group, $n=8$ for the LPS group, and $n=8$ for the E. faecium group.

a,b Within a row, means with different superscripts differ $(p<0.05)$.

\section{Discussion}

After weaning, the changes of diet from the sow milk to solid food often weaken the ability of piglets to adapt to the environment. Weaned piglets are easily infected by pathogenic microorganisms. The proliferation of pathogenic microorganisms in the host is usually accompanied by reduced feed intake, activation of the immune system, and growth retardation [28-30]. Therefore, post-weaning diarrhea is a very common disease that seriously threatens the healthy growth of weaned piglets [31-33]. In recent years, probiotics have been used as feed additives with an in-depth study of animal microecology [34,35].

Although many probiotics are currently used as feed additives, the actual effects of microecological agents prepared by different probiotics are different in animals [36,37]. Some studies have reported that probiotics must adhere to the intestinal epithelium cells and colonize in animal intestines to function [11-14]. However, the high temperature produced during feed pelleting, the acidic environment of the stomach, and high concentrations of bile salts in the animal gastrointestinal tract can kill the vast majority of microorganisms [15-19]. Therefore, probiotics that can be used to prepare microecological agents must have the biological characteristics of acid, salt, and high-temperature resistance.

Some studies have shown that probiotics can promote the healthy growth of animals by the formation of dominant microflora to inhibit the survival of pathogens and promote nutrient absorption in the intestine [4,38]. Therefore, probiotics used to prepare microecological agents must have the ability to regulate intestinal flora and enhance intestinal barrier function. In this study, the bacteriostatic effects of 10 probiotic strains isolated from intestinal contents in pigs fed commercial compound feeds were determined. Four probiotic strains (E. lactis, E. faecium R1, E. faecium R2, and Probiotic G-G) showed a highly effective bacteriostasis against pathogenic $E$. coli K88 compared with other strains in vitro. In addition, probiotics used as feed additives not only possess effective antimicrobial effects but also need to be successfully colonized in animal intestines. Since the $\mathrm{pH}$ in the pig's stomach is 2-3.5, probiotics with acid resistance can survive in a pig's stomach and enter the intestine. Once probiotics enter the duodenum, they will encounter a high concentration of bile salts $(0.03-0.3 \%)$ secreted by the liver, which possesses bacteriostatic activity and can destroy the cell membrane by causing cell membrane rupture and membrane protein dissociation [22,23]. In addition to the two aspects mentioned above, the high temperature $\left(90{ }^{\circ} \mathrm{C}\right)$ produced during feed pelleting will cause the death of most probiotics. Therefore, before preparing probiotic preparations, the biological characteristics of selected probiotics 
need to be determined. The results of this study showed that E. faecium R1 and E. lactis not only had effective bacteriostatic properties but also had relatively higher survival rates than the other two strains (E. faecium R2 and Probiotic G-G) under acidic condition ( $\mathrm{pH} 2.5$ ). Moreover, E. faecium R1 was much more tolerant to pig bile salt solution than E. lactis. E. faecium $\mathrm{R} 1$ had the strongest heat resistance among the four strains at $60{ }^{\circ} \mathrm{C}$, and its survival rate was more than $80 \%$. Therefore, E. faecium $\mathrm{R} 1$ can be added to pig feed as a candidate probiotic strain because of its stable biological characteristics.

Previous studies have shown that E. faecium can adhere to the intestinal epithelium cells and colonize in the human and animal digestive tract, and secrete various lactic acid, amino acids, and vitamins in the process of metabolism, and promote the digestion and absorption of nutrients $[10,39,40]$. Taras et al. reported that although dietary supplementation with E. faecium reduced the number of pathogens in the intestine of weaned piglets and lowered the diarrhea rate, no significant difference was found [41]. However, our results showed that dietary supplementation with E. faecium R1 significantly lowered the diarrhea rate in weaned piglets. Strompfová et al. reported that dietary supplementation with $E$. faecium EK13 did not significantly improve feed conversion and growth performance of weaned piglets [42]. However, this study showed that dietary supplementation with $E$. faecium R1 significantly increased the feed conversion rate of weaned piglets after feeding for 15 days. The daily gain of weaned piglets in this study has also been increased. These results indicated that dietary supplementation with E. faecium R1 improved the growth performance of weaned piglets.

Although our results showed that dietary supplementation with E. faecium R1 can significantly improve the growth performance of weaned piglets, the underlying mechanism is still unknown. The changes in blood biochemical indexes in pigs are a reflection of changes in cell permeability and metabolic function of animals [43]. Some studies have shown that increased activity of alanine aminotransferase (ALT), aspartate aminotransferase (AST), and alkaline phosphatase (ALP) in the blood is usually a marker of the stress response and also indicates liver damage $[44,45]$. Consistent with previous studies indicating that LPS could induce the elevation of liver damage-related indicators in blood [24,26], the results of this study showed that the activity of AST in the blood of piglets was significantly increased after the LPS challenge. However, dietary supplementation with E. faecium R1 significantly decreased the activity of AST in the blood. The above results revealed that dietary supplementation with E. faecium R1 can attenuate liver injury in LPS-challenged piglets. Glucagon (GC) is a hormone secreted by islet B cells to increase blood sugar concentration. When the body is under intense stress, the secretion of glucagon is increased significantly, which promotes the rise of blood sugar and provides energy for the body to fight against stress [46]. The results of this study showed that dietary supplementation with E. faecium R1 promoted the secretion of glucagon when piglets were challenged with LPS. Previous studies have shown that cortisol (COR) is a hormone produced in response to stress [47]. After the LPS challenge, the contents of COR in the blood of piglets fed with or without dietary supplementation of E. faecium R1 were increased, which showed that E. faecium R1 cannot inhibit the stress response. These results revealed that E. faecium R1 can help piglets cope with stress response by effectively increasing the concentration of blood glucagon. Previous studies have reported that prostaglandin (PGE2) is a kind of inflammatory mediator that can cause a typical inflammation reaction [48]. The results of this study showed that dietary supplementation with E. faecium R1 significantly decreased the content of PGE2 in the liver of piglets challenged with LPS.

Oxidative stress refers to the excessive production of free radicals such as oxygen free radicals (ROS) and reactive nitrogen free radicals (RNS), which can cause cytotoxic effects. If the antioxidants in the body can't remove the oxides timely, the balance between the oxidant production system and the antioxidant system is broken, then the oxidative injury will occur in the body [49]. Normally, the body can scavenge excessive free radicals by antioxidant enzymes and antioxidants to protect the body from oxidative damage [24,49]. Enzymes of the antioxidant defense system mainly include SOD, CAT, GSH, GSH-Px (glutathione 
peroxidase) [50]. Catalase (CAT) is an enzyme that catalyzes the decomposition of hydrogen peroxide into oxygen and water, alleviates oxidative stress, and improves the antioxidant capacity of the body [51]. The result of this study showed that dietary supplementation with E. faecium R1 significantly increased the activity of CAT in the pancreas. Previous studies have shown that $\mathrm{tNOS}$ is activated to produce a large amount of NO which easily binds to $\mathrm{O}^{2-}$ to form $\mathrm{ONOO}^{-}$to induce lipid peroxidation injury [52]. The result of this study showed that dietary supplementation with E. faecium R1 significantly decreased the activity of tNOS in the pancreas. As for malondialdehyde (MDA), a cytotoxic oxidation product, which can be significantly increased under the body's oxidative stress [4,49]. Dietary supplementation with E. faecium R1 significantly reduced the content of MDA in the liver. These results revealed that dietary supplementation with E. faecium R1 can improve the antioxidant capacity of piglets by significantly increasing CAT activity in the pancreas, and decreased tNOS activity in the pancreas and MDA content in the liver.

The small intestine is the primary digestion and absorption organ of nutrients. When the morphology and function of intestinal in piglets are damaged, the piglet growth will be affected. D-xylose is a pentacarbose that can be absorbed by the small intestine without digestion and is generally not utilized by animals [53]. The determination of D-xylose in the blood can indirectly reflect the intestinal structure and function of piglets. Alkaline phosphatase (AKP) is a membrane-binding enzyme widely distributed in animal liver, bone, intestinal mucosa, and other tissues; it can decompose phosphate bonds in an alkaline environment [4]. Studies have reported that AKP plays an important role in the metabolic process of animals and serum AKP is closely related to the absorption and transportation of proteins, fats, and sugars [4,54]. Meanwhile, AKP in intestinal mucosal epithelial cells is a marker enzyme, which is closely related to intestinal digestion and absorption and can promote the absorption of amino acids, lipids, glucose, vitamin D, calcium, and phosphorus in the intestine $[55,56]$. Other studies reported that AKP has an important role in the clearance and detoxification of endotoxin, such as lipopolysaccharide produced by harmful microorganisms in the intestinal tract, and the protection of intestinal health [56]. Carbohydrates usually account for 50\% to $80 \%$ of animal diets, and all carbohydrates are absorbed only after they are hydrolyzed into monosaccharides in the small intestine [49,57]. Intestinal disaccharidases are the key enzymes for carbohydrate digestion and absorption. The activity of disaccharidase can be used as a measurement of the development and function of intestinal mucosal epithelial cells [58]. Polysaccharides and oligosaccharides must be firstly degraded to disaccharides by digestive enzymes, and then disaccharides are decomposed into monosaccharides by disaccharidase before they can be absorbed $[27,49,59]$. In this study, LPS challenge significantly reduced the contents of D-xylose, AKP, disaccharidases, revealing that LPS challenge can significantly decrease the absorption function of the small intestine in piglets. However, dietary supplementation with E. faecium R1 did not significantly alter the content of D-xylose, AKP, disaccharidases, indicating that $E$. faecium R1 did not significantly improve intestinal absorption function in piglets. Moreover, the results showed that dietary supplementation with E. faecium R1 improved enterocyte proliferation in piglets, which is indicated by the significant increase of the gene expression of villin in jejunum and ileum and anti-apoptotic Bcl-xL in the ileum. Meanwhile, compared with the LPS group, dietary supplementation with E. faecium R1 significantly up-regulated the expression of the $p B D-1$ gene in the ileum of piglets. pBD-1 is a widely distributed defensin in pigs and has broad-spectrum antimicrobial activity.

\section{Conclusions}

In summary, E. faecium R1 can be used as a safe and effective alternative to antibiotics because of the biological characteristics of acid, salt, and high-temperature resistance, as well as dietary supplementation with E. faecium R1 not only improves the intestinal function of piglets by decreasing diarrhea incidence but also alleviates intestinal and liver injury in piglets challenged by LPS. 
Author Contributions: Conceptualization, Y.H., Y.Z., T.W. and Z.C.; methodology, D.Z. and L.W.; software, D.Y.; validation, Y.M., Z.Z., J.T. and Q.W.; formal analysis, Y.Z., D.Z. and L.W; investigation, D.Z.; resources, T.W.; data curation, Z.C.; writing-original draft preparation, Y.Z.; writing-review and editing, Y.H. and Y.Z.; visualization, D.Z.; supervision, L.W.; project administration, D.Z.; funding acquisition, Y.H. All authors have read and agreed to the published version of the manuscript.

Funding: This work was funded by the National Key R\&D Program of China (grant number 2016YFD0501210), the Hubei Provincial Key R\&D Program (2019ABA083), and the Program of National Agricultural Research Outstanding Talents of China (2015). We thank our students and technicians for their contributions to this research. And this work was supported by the Open Project of Hubei Key Laboratory of Animal Nutrition and Feed Science (grant number DKXY2020006).

Institutional Review Board Statement: The study was approved by the Animal Care and Use Committee at Wuhan Polytechnic University (protocol code WPU202011002, 02/11/2020).

Data Availability Statement: The data presented in this study are available on request from the corresponding author. The data are not publicly available due to privacy.

Acknowledgments: We thank our students and technicians for their contributions to this research.

Conflicts of Interest: The authors declare no conflict of interest.

\section{References}

1. De, G.A.; Resink, J.W.; Van Hees, H.M.; Ruuls, L.; Klaassen, G.J.; Rouwers, S.M.; Stockhofe-Zurwieden, N. Supplementation of piglets with nutrient-dense complex milk replacer improves intestinal development and microbial fermentation. J. Anim. Sci. 2016, 94, 1012-1019.

2. Moeser, A.J.; Pohl, C.S.; Rajput, M. Weaning stress and gastrointestinal barrier development: Implications for lifelong gut health in pig. Anim. Nutr. 2017, 3, 313-321. [CrossRef]

3. Souza, T.C.R.; Landín, G.M.; García, K.E. Some physiological and nutritional factors affecting the incidence of post-weaning diarrhea in piglets. Vet. Mex. 2011, 41, 275-288.

4. Wu, T.; Li, K.; Yi, D.; Wang, L.; Zhao, D.; Lv, Y.; Zhang, L.; Chen, H.B.; Ding, B.Y.; Hou, Y.Q.; et al. Dietary supplementation with trihexanoin enhances intestinal function of weaned piglets. Int. J. Mol. Sci. 2018, 19, 3277. [CrossRef] [PubMed]

5. Montagne, L.; Boudry, G.; Favier, C.; Le Huërou-Luron, I.; Lallès, J.P.; Sève, B. Main intestinal markers associated with the changes in gut architecture and function in piglets after weaning. Br. J. Nutr. 2007, 97, 45-57. [CrossRef]

6. Reid, G. Probiotics to prevent the need for, and augment the use of, antibiotics. Can. J. Infect. Dis. Med. Microbiol. 2006, 17, 291-295. [CrossRef] [PubMed]

7. Simon, O. Micro-organisms as feed additives-probiotics. Adv. Pork Prod. 2005, 16, 161-167.

8. Jiraphocakul, S.; Sullivan, T.W.; Shahani, K.M. Influence of a dried Bacillus subtilis culture and antibiotics on performance and intestinal microflora in turkeys. Poult. Sci. 1990, 69, 1966-1973. [CrossRef] [PubMed]

9. Shi, L.H.; Balakrishnan, K.; Thiagarajah, K.; Ismail, N.I.M.; Yin, O.S. Beneficial properties of probiotics. Trop. Life Sci. Res. 2016, 27, 73-90.

10. Nolasco-Hipolito, C.; Zarrabal, O.C.; Kamaldin, R.M.; Teck-Yee, L.; Lihan, S.; Bujang, K.B.; Nitta, Y. Lactic acid production by Enteroccocus faecium in liquefied sago starch. AMB Express 2012, 2, 53. [CrossRef] [PubMed]

11. Nilsson, O. Vancomycin resistant enterococci in farm animals-occurrence and importance. Infect. Ecol. Epidemiol. 2012, 2, 16959. [CrossRef] [PubMed]

12. Hendrickx, A.P.A.; Kamer, D.V.D.; Willems, R.J.L. Primary murine mucosal response during cephalosporin-induced intestinal colonization by Enterococcus faecium. Microbiol. Open 2018, 7, e00602. [CrossRef] [PubMed]

13. Rinne, M.; Kalliomaki, M.; Arvilommi, H.; Salminen, S.; Isolauri, E. Effect of probiotics and breastfeeding on the bifidobacterium and lactobacillus/enterococcus microbiota and humoral immune responses. J. Pediatr. 2005, 147, 186-191. [CrossRef]

14. Pultz, N.J.; Stiefel, U.; Ghannoum, M.; Helfand, M.S.; Donskey, C.J. Effect of parenteral antibiotic administration on establishment of intestinal colonization by Candida glabrata in adult mice. Antimicrob. Agents Chemother. 2005, 49, 438-440. [CrossRef]

15. Wedajo, B. Lactic acid bacteria: Benefits, selection criteria and probiotic potential in fermented food. J. Probiotics Health 2015, 3, 129. [CrossRef]

16. Begley, M.; Hill, C.; Gahan, C.G. Bile salt hydrolase activity in probiotics. Appl. Environ. Microbiol. 2006, 72, 1729-1738. [CrossRef]

17. Ruiz, L.; Margolles, A.; Sánchez, B. Bile resistance mechanisms in Lactobacillus and Bifidobacterium. Front. Microbiol. 2013, 4, 396. [CrossRef]

18. Timmerman, H.M.; Veldman, A.; Van den Elsen, E.; Rombouts, F.M.; Beynen, A.C. Mortality and growth performance of broilers given drinking water supplemented with chicken-specific probiotics. Poult. Sci. 2006, 85, 1383-1388. [CrossRef] [PubMed]

19. Kang, M.S.; Kim, Y.S.; Lee, H.C.; Lim, H.S.; Oh, J.S. Comparison of temperature and additives affecting the stability of the probiotic weissella cibaria. Chonnam Med. J. 2012, 48, 159-163. [CrossRef] [PubMed] 
20. Samarasinghe, K.; Messikommer, R.; Wenk, C. Activity of supplemental enzymes and their effect on nutrient utilization and growth performance of growing chickens as affected by pelleting temperature. Arch. Tierernahr. 2000, 53, 45-58. [CrossRef] [PubMed]

21. Cenci, G.; Trotta, F.; Caldini, G. Tolerance to challenges miming gastrointestinal transit by spores and vegetative cells of Bacillus clausii. J. Appl. Microbiol. 2006, 101, 1208-1215. [CrossRef] [PubMed]

22. Tuomola, E.; Crittenden, R.; Playne, M.; Isolauri, E.; Salminen, S. Quality assurance criteria for probiotic bacteria. Am. J. Clin. Nutr. 2001, 73, 393S-398S. [CrossRef] [PubMed]

23. Zhou, Q.; Wang, S.S.; Yang, G.; Zhao, W.; Li, H.L. Development and evaluation of a herbal formulation with anti-pathogenic activities and probiotics stimulatory effects. J. Integr. Agric. 2016, 15, 1103-1111. [CrossRef]

24. Zhao, D.; Wu, T.; Yi, D.; Wang, L.; Li, P.; Zhang, J.M.; Hou, Y.Q.; Wu, G.Y. Dietary supplementation with Lactobacillus casei alleviates lipopolysaccharide-induced liver injury in a porcine model. Int. J. Mol. Sci. 2017, 18, 2535. [CrossRef]

25. Hou, Y.Q.; Wang, L.; Yi, D.; Ding, B.Y.; Yang, Z.G.; Li, J.; Chen, X.; Qiu, Y.S.; Wu, G.Y. N-acetylcyseine reduces inflammation in the small intestine by regulating redox, EGF and TLR4 signaling. Amino Acids 2013, 45, 513-522. [CrossRef]

26. Wang, L.; Yi, D.; Hou, Y.Q.; Ding, B.Y.; Li, K.; Li, B.C.; Zhu, H.L.; Liu, Y.L.; Wu, G.Y. Dietary supplementation with a-ketoglutarate activates mTOR signaling and enhances energy status in skeletal muscle of lipopolysaccharide-challenged piglets. J. Nutr. 2016, 146, 1514-1520. [CrossRef]

27. Yi, D.; Hou, Y.Q.; Xiao, H.; Wang, L.; Zhang, Y.; Chen, H.B.; Wu, T.; Ding, B.Y.; Hu, C.A.A.; Wu, G.Y. N-Acetylcysteine improves intestinal function in lipopolysaccharides-challenged piglets through multiple signaling pathways. Amino Acids 2017, 49, 1915-1929. [CrossRef]

28. He, Q.H.; Tang, H.R.; Ren, P.P.; Kong, X.F.; Wu, G.Y.; Yin, Y.L.; Wang, Y.L. Dietary supplementation with L-Arginine partially counteracts serum metabonome induced by weaning stress in piglets. J. Proteome Res. 2011, 10, 5214-5221. [CrossRef]

29. Schweiger, M.; Steffl, M.; Amselgruber, W.M. Differential expression of EGF receptor in the pig duodenum during the transition phase from maternal milk to solid food. J. Gastroenterol. 2003, 38, 636-642. [CrossRef]

30. Lesniewsk, V.; Lærke, H.N.; Hedemann, M.S.; Hojsgaard, S.; Jensen, B.B. The effect of change of the diet and feeding regimen at weaning on duodenal myoelectrical activity in piglets. Anim. Sci. 2000, 71, 443-451. [CrossRef]

31. Rhouma, M.; Fairbrother, J.M.; Beaudry, F.; Letellier, A. Post weaning diarrhea in pigs: Risk factors and non-colistin-based control strategies. Acta Vet. Scand. 2017, 59, 31. [CrossRef] [PubMed]

32. Jasovský, D.; Littmann, J.; Zorzet, A.; Cars, O. Antimicrobial resistance-a threat to the world's sustainable development. Upsala J. Med. Sci. 2016, 121, 159-164. [CrossRef]

33. Vondruskova, H.; Slamova, R.M.; Trckova, Z.Z.; Pavlik, I. Alternatives to antibiotic growth promoters in prevention of diarrhoea in weaned piglets: A review. Vet. Med. 2010, 55, 199-224. [CrossRef]

34. Liu, Y.; Espinosa, C.D.; Abelilla, J.J.; Casas, G.A.; Lagos, L.V.; Lee, S.A.; Kwon, W.B.; Mathai, J.K.; Navarro, D.M.D.L.; Jaworski, N.W.; et al. Non-antibiotic feed additives in diets for pigs: A review. Anim. Nutr. 2018, 4, 113-125. [CrossRef] [PubMed]

35. Cottingim, K.M.; Verma, H.; Urriola, P.E.; Sampedro, F.; Shurson, G.C.; Goyal, S.M. Feed additives decrease survival of delta coronavirus in nursery pig diets. Porc. Health Manag. 2017, 3, 5. [CrossRef] [PubMed]

36. Cerbo, A.; Palmieri, B.; Aponte, M.; Morales-Medina, J.C.; Iannitti, T. Mechanisms and therapeutic effectivenessof lactobacilli. J. Clin. Pathol. 2016, 69, 187-203. [CrossRef] [PubMed]

37. Oh, J.H.; Jang, Y.S.; Kang, D.; Chang, D.K.; Min, Y.W. Efficacy and safety of new lactobacilli probiotics for unconstipated irritable bowel syndrome: A randomized, double-blind, placebo-controlled trial. Nutrients 2019, 11, 2887. [CrossRef]

38. Glenwright, A.J.; Pothula, K.R.; Bhamidimarri, S.P.; Chorev, D.S.; Baslé, A.; Firbank, S.J.; Zheng, H.J.; Robinson, C.V.; Winterhalter, M.; Kleinekathöfer, U.; et al. Structural basis for nutrient acquisition by dominant members of the human gut microbiota. Nature 2017, 541, 407-411. [CrossRef]

39. Lan, R.X.; Kim, I. Enterococcus faecium supplementation in sows during gestation and lactation improves the performance of sucking piglets. Vet. Med. Sci. 2020, 6, 92-99. [CrossRef]

40. Schittler, L.; Perin, L.M.; de Lima Marques, J.; Lando, V.; Todorov, S.D.; Nero, L.A.; da Silva, W.P. Isolation of Enterococcus faecium, characterization of its antimicrobial metabolites and viability in probiotic Minas Frescal cheese. J. Food Sci. Technol. 2019, 56, 5128-5137. [CrossRef]

41. Taras, D.; Vahjen, W.; Macha, M.; Simon, O. Performance, diarrhea incidence, and occurrence of Escherichia coli virulence genes during long-term administration of a probiotic. J. Anim. Sci. 2006, 84, 608-617. [CrossRef] [PubMed]

42. Strompfová, V.; Marcináková, M.; Simonová, M.; Gancarcíková, S.; Jonecová, Z.; Sciranková, L.; Koscová, J.; Buleca, V.; Cobanová, K.; Lauková, A. Enterococcus faecium EK13-an enterocin a-producing strain with probiotic character and its effect in piglets. Anaerobe 2006, 12, 242-248. [CrossRef] [PubMed]

43. Yi, D.; Fang, Q.H.; Hou, Y.Q.; Wang, L.; Xu, H.W.; Wu, T.; Gong, J.H.; Wu, G.Y. Dietary supplementation with oleum cinnamomi improves intestinal functions in piglets. Int. J. Mol. Sci. 2018, 19, 1284. [CrossRef] [PubMed]

44. Schindhelm, R.K. Serum alanine aminotransferase, metabolic syndrome, and cardiovascular disease in an Australian population. Am. J. Gastroenterol. 2009, 105, 2857-2858. [CrossRef]

45. Li, Q.; Liu, Y.L.; Che, Z.Q.; Zhu, H.L.; Meng, G.Q.; Hou, Y.Q.; Ding, B.Y.; Yin, Y.L.; Chen, F. Dietary L-arginine supplementation alleviates liver injury caused by E.coli lipopolysaccharide in weaned pigs. Innate Immun. 2012, 18, 804-814. [CrossRef] 
46. Lazo-de-la-Vega-Monroy, M.L.; Larrieta, E.; Tixi-Verdugo, W.; Ramírez-Mondragón, R.; Hernández-Araiza, I.; German, M.S.; Fernandez-Mejia, C. Effects of dietary biotin supplementation on glucagon production, secretion, and action. Nutrition 2017, 43-44, 47-53. [CrossRef]

47. Glienke, K.; Piefke, M. Stress-related cortisol responsivity modulates prospective memory. J. Neuroendocrinol. 2017, 29 , e12544. [CrossRef]

48. Kawahara, K.; Hohjoh, H.; Inazumi, T.; Tsuchiya, S.; Sugimoto, Y. Prostaglandin E2-induced inflammation: Relevance of prostaglandin E receptors. Biochim. Biophys. Acta 2015, 1851, 414-421. [CrossRef]

49. Wu, T.; Zhang, Y.; Lv, Y.; Li, P.; Yi, D.; Wang, L.; Zhao, D.; Chen, H.B.; Gong, J.H.; Hou, Y.Q. Beneficial impact and molecular mechanism of Bacillus coagulans on piglets' intestine. Int. J. Mol. Sci. 2018, 19, 2084. [CrossRef]

50. Harris, E.D. Regulation of antioxidant enzymes. FASEB J. 1992, 122, 2675-2683. [CrossRef]

51. Wang, L.; Hou, Y.Q.; Yi, D.; Li, Y.T.; Ding, B.Y.; Zhu, H.L.; Liu, J.; Xiao, H.; Wu, G.Y. Dietary supplementation with glutamate precursor $\alpha$-ketoglutarate attenuates lipopolysaccharide-induced liver injury in young pigs. Amino Acids 2015, 47, 1309-1318. [CrossRef]

52. Zhou, X.; Yuan, D.; Wang, M.X.; He, P.N. $\mathrm{H}_{2} \mathrm{O}_{2}$-induced endothelial NO production contributes to vascular cell apoptosis and increased permeability in rat venules. Am. J. Physiol. Heart. Circ. Physiol. 2013, 304, 82-93. [CrossRef] [PubMed]

53. Wang, L.; Zhou, J.; Hou, Y.Q.; Yi, D.; Ding, B.Y.; Xie, J.Q.; Zhang, Y.; Chen, H.B.; Wu, T.; Zhao, D.; et al. N-Acetylcysteine supplementation alleviates intestinal injury in piglets infected by porcine epidemic diarrhea virus. Amino Acids 2017, 49, 1931-1943. [CrossRef] [PubMed]

54. Toofanian, F.; Targowski, S.P. Fetel development and distribution of intestinal alkaline phosphatase in rabbit. Res. Vet. Sci. 1982, 32, 303-305. [CrossRef]

55. Wang, M.X.; Xie, Z.Y.; Li, L.; Chen, Y.X.; Li, Y.; Wang, Y.Y.; Lu, B.Y.; Zhang, S.B.; Ma, F.L.; Ma, C.W.; et al. Supplementation with compound polysaccharides contributes to the development and metabolic activity of young rat intestinal microbiota. Food Funct. 2019, 10, 2658-2675. [CrossRef]

56. Hodinra, R.A.; Chamberlain, S.M.; Meng, S. Patern of rat intestinal brush-border enzyme gene expression changes with epithelial growth state. Am. J. Physiol. 1995, 269, 385-391. [CrossRef] [PubMed]

57. Drozdowski, L.A.; Thomson, A.B.R. Intestinal sugar transport. World J. Gastroenterol. 2006, 12, 1657-1670. [CrossRef]

58. Lee, S.H.; Yu, S.Y.; Nakyama, J.; Khoo, K.H.; Stone, E.L.; Fukuda, M.N.; Marth, J.D.; Fukuda, M. Core2 O-glycan structure is essential for the cell surface expression of sucrase isomaltase and dipeptidyl peptidase-IV during intestinal cell differentiation. $J$. Biol. Chem. 2010, 285, 37683-37692. [CrossRef]

59. Wu, G.D.; Chen, J.; Hoffmann, C.; Bittinger, K.; Chen, Y.Y.; Keilbaugh, S.A.; Bewtra, M.; Knights, D.; Walters, W.A.; Knight, R.; et al. Linking longterm dietary patterns with gut microbial enterotypes. Science 2011, 334, 105-108. [CrossRef] 